\title{
Improved techniques for rearing mud crab Scylla paramamosain (Estampador 1949) larvae
}

\author{
Truong Trong Nghia ${ }^{1}$, Mathieu Wille ${ }^{2}$,Tran Cong Binh ${ }^{1}$, Hoang Phuoc Thanh ${ }^{1}$, Nguyen Van Danh ${ }^{1}$ \& \\ Patrick Sorgeloos ${ }^{2}$ \\ ${ }^{1}$ College of Aquaculture and Fisheries, Can Tho Inniversity, Can Tho City. Vietram \\ ${ }^{2}$ Laboratory of Aquacuiture \& Artemia Reference Center, Ghent University, Ghent Belgium
}

Correspondence: T' Trong Nghia, College of Aquaculture and Fisheries, Can Tho University, 3rd February avenue, Campus II. Can Tho City, Tietnam. R-mail ttnghia@ictu.eda.vn

\begin{abstract}
A series of rearing trials in small $1 \mathrm{~L}$ cones and large tanks of 30-100 L were carried out to develop optimal rearing techniques for mud crab (Scylla paramamosain) Iarvae. Using water exchange (discontinuous partial water renewal or continuous treatment through biofiltration) and micro-algae (Chlorella or Chaetoceros) supplementation (daily supplementation at $0.1-0.2$ million cells $\mathrm{mL}^{-1}$ or maintenance at $1-2$ millions cells $\mathrm{mr}^{-1}$ ), six different types of rearing systems were tried. The combination of a green-water batch system for early stages and a recirculating system with micro-algae supplementation for later stages resulted in the best overali perlormance of the crab larvae. No clear effects of $\mathrm{crab}$ stocking density (50-200 iarvae $\left.\mathrm{L}^{-1}\right)$ and rotifer (30-60 rotifers $\mathrm{mL}^{-1}$ ) and Artemia density (10$20 \mathrm{~L}^{-1}$ ) were observed. A stocking density of 100-150 zoea I (Z1) $\mathrm{L}^{-1}$, combined with rotifer of $30-45 \mathrm{~mL}^{-1}$ for early stages and Artemia feeding at $10-15$ nauplii $\mathrm{mL}^{-1}$ for $\mathrm{Z3}-\mathrm{Z} 5$ seemed to produce the best performance of S. paramamosain larvae. Optimal rations for crab larvae should, however, be adjusted depending on the species. larval stage, larval status, prey size, rearing system and techniques. A practical feeding schedule could be to increase live food density from 30 to 45 rotifers $\mathrm{mL}^{-1}$ from $\mathrm{Zl}$ to $\mathrm{Z} 2$ and increase the number of Artemia nauplii $\mathrm{mL}^{-1}$ from 10 to 1.5 from $\mathrm{Z3}$ to $\mathrm{Z} 5$. Bacterial disease remains one of the key factors underlying the high morlality in the zoea stages. Further research to develop safe prophylactic treatments is therefore warranted. Combined with proper live food enrichment techniques. application of these findings has sustained a survival
\end{abstract}

rate from $\mathrm{Z1}$ to crab $1-2$ stages in large rearing tanks of 10-15\% (maximum 30\%).

Keywords: Scylla paramamosain, rearing techniques, water exchange, micro-algae, larval density, life food density, prophylaxis

\section{Introduction}

Aquaculture of mud crabs, Scylla spp., contributes a large proportion to the world production of the genus (FAO 1999). Moreover, mud crabs represent a valuable component of small-scaled coastal fisheries in many countries in tropical and subtropical Asia, for which there has been a general trend of increased exploitation in recent years (Angell 1992; Keenan 1999a). In Vietnam, the mud crab Scylla paramamosain is the second most important marine species next to shrimp, being cultured widely in the coastal area. However, mud crab farming currently relies entirely on the wild for seed stock and the main obstacle for expansion is the unavailability of hatchery-reared seed (Liong 1992; Rattanachote \& Dangwatanakul 1992; Keenan 1999a; Sheliey \& Field 1999; Mann Asakawa, Pizzuto, Keenan \& Brock 2001; Xuan 2001).

Rearing techniques, disease and nutrition are the three majn areas of research that have supported commercial production of marine fish and crustacean larvae (Sorgelons \& Léger 1992). These three aspects are to a large extent interconnected and developing hatchery techniques for a 'new' species is not possible unless all the areas are addressed. The 
design of rearing systems covers more than purely technical aspects. Sub-optimal rearing conditions (e.g. physical stress, lack of oxygen or sub-optimal water quality) aflect larval health and can cause mass mortality due to disease outbrealss. Similarly, system design influences (live) food quality and its availability to the predator larvae.

There has been a great deal of progress in marine larval rearing technology since its beginning in the 1960s (Shelbourne 1964; Howell, Day, Fllis \& Baynes 1998). Many of these technical improvements developed over the past decades could be applied for mud crab with some modifications. An overview of the rearing systems currently applied for larviculture of mud crabs was presented by Davis (2003). Althongh knowledge has been obtained from these systerns, there is a need to further optimize rearing techniques in order to maximize larval survival and qualíty. Furthermore, techniques should be adapted for each Srylla species (Keenan. Davie \& Mann 1998; Keenan $1999 \mathrm{~b}$ ) in relation to local conditions (seawater source, status of hatchery management. local resources). The aim of this research is to adapt the existing rearing systems for larviculture to mud crab species ( $S$. paramamossin being the test crse) and to improve other techniques in order to maximize larral survival and quality.

\section{Materials and methods}

\section{Snurce of larvae}

Gravid crabs were bought from local markets and transported to the hatchery. Before stocking in the hatchery, the crabs were subjected to a bath of $100 \mu \mathrm{LL}^{-1}$ of a $40 \%$ formalin solution for $1 \mathrm{~h}$. The crabs were stocked individually in $100 \mathrm{~L}$ compartments of a rooled $2 \times 2 \times 0.5 \mathrm{~m}$ cement tanis, equipped with a biofilter. Rearing water of $30 \pm 1 \mathrm{gL}^{-1}$ salinity was diluted from orine $(90-$ III $\mathrm{g} \mathrm{L}^{-1}$ ) with tap water and chlorinated before use. Ambient temperature fluctuated slightly around $28^{\circ} \mathrm{C}$. Every crab was fed a daily ration of $10-15 \mathrm{~g}$ of fresh marine squid, bivalve or shrimp meat alternately.

After 3-5 days of accimation, unilateral eyestalk ablation was applied to induce spawning. After spawning, berried crabs were again subjected to a $100 \mu \mathrm{L} \mathrm{I}_{\mathrm{r}}{ }^{-1}$ formalin bath for $1 \mathrm{~h}$ and translerred to a $70 \mathrm{~L}$ plastic tank connected to a biofilter for egg incubation. Daily management consisted of siphnning out waste materials and shedded eggs from the tank bottom and controlling the termperature $\left(30^{\circ} \mathrm{C}\right)$, salinity $\left(30 \mathrm{gL}^{-1}\right)$ and ammonia and nitrite levels. Every other day, the crabs were placed in a $50 \mu \mathrm{LL}^{-1}$ formalin bath for $1 \mathrm{~h}$ to reduce or prevent infestation of the eggs with fungi and bacteria. During egg incubation, the crabs were not fed

one to two days before hatching, the berried Semale was moved to a $500 \mathrm{~L}$ fibreglass tank. When the hatching process was completed, larvae were selected based on their phototactic behaviour. Aeration in the hatching tank was turned off for several minutes and the active larvae swimming up to the surface were collected by gentle scooping.

The larvae were then transferred to the rearing containers. Acclimation was performed by placing the larvae in a $50 \mathrm{~L}$ plastic mesh bucket and slowly rinsing them with water from the larval rearing containers for 20-30 min before release.

\section{Food and feeding}

\section{Micro-algae culture}

Starting cultures of the micro-algae Chaetoceros calcitrans and Chlorella vulgaris were maintained indoors with Walne solution in seawater of $30 \mathrm{~g} \mathrm{~L}^{-1}$ at $25^{\circ} \mathrm{C}$. large-scale production was performed indocrs in $500 \mathrm{~L}$ tanks under a transparent roof. A haemocytometer was used to count micro-algal densities.

\section{Rotifer culture and enrichment}

The same Brachionus plicatilis L-strain with a lorica length and width of $164 \pm 22$ and $120 \pm 22 \mu \mathrm{m}$, respectively, was used in all the experiments. Rotifers were cultured indoors in $100 \mathrm{~L}$ fibreglass tanks operated in a batch mode. following the procedure described in Sorgeloos and Javens (1996). Rotifers were initially grown on baker's yeast, but later on led Culture Selco ${ }^{*}$ (INVE Aquaculture, Dendermonde Belgium) before leeding to the larvae. Temperature and salinity were controlled at $25^{\circ} \mathrm{C}$ and $25 \mathrm{~g} \mathrm{~L}^{-1}$ respectively. They were harvested through a $60 \mu \mathrm{m}$ screen and rinsed thoroughly.

Rotifers were enriched with micro-algae or artificial enrichment media befcre being fed to the crab larvae Enrichment with Chlorella was performed at a density of $5 \times 10^{\text {5 }}$ cells $\mathrm{mL}^{-1}$ for $3 \mathrm{~h}$ (Dhert 1996). Rotifers were also enriched with Dry Immune Selco ${ }^{\text {* }}$ (DIS ${ }^{11}$. INVE Aquaculture), using two separate doses of $0.05 \mathrm{~g} \mathrm{~L}^{-1}$ at a 3 -h interval. Enrichment was performed at a density of 500 rotifers $\mathrm{mI}^{-1}$. The water in the enrichment vessel was slowly heated to 
Table 1 Overview of larval rearing systems applied in this study based on the method of water exchange and micro-algae supplementation

\begin{tabular}{|c|c|c|}
\hline \multirow[b]{2}{*}{ Algae supplementaticn } & \multicolumn{2}{|l|}{ Water exchange } \\
\hline & $\begin{array}{l}\text { Discentinuous manual } \\
\text { partlal waler renewal }\end{array}$ & $\begin{array}{l}\text { Continuous water } \\
\text { treatment through the } \\
\text { use ol a biafilter }\end{array}$ \\
\hline Nn micro-algae suppiemented (indoors) & Clear-Batch systern & Clear-Recire system \\
\hline $\begin{array}{l}\text { Micro-algae supplemented at low levels to provide } \\
\text { extra lood for ilve preys (indoors or outdoors) }\end{array}$ & Algae-Batch system & Algae-Recire system \\
\hline $\begin{array}{l}\text { Micro-aigae supplemented at a high concentration } \\
\text { and self-sustainable under nakural sunlight as an } \\
\text { extra food for live prey and waler conditioning (outdoors) }\end{array}$ & Green-Batch system & $\begin{array}{l}\text { Green-Recirc system } \\
\text { (Combination of Green-Baich and } \\
\text { Algae-Recirc sysiem at eariy and late } \\
\text { larval stages respectively) }\end{array}$ \\
\hline
\end{tabular}

$29-30{ }^{\circ} \mathrm{C}$ to avold exposing the rotifers to thermal shock when they were added to the larval rearing tanks. Befcre being fed to the larvae, enriched rotifers were rinsed and re-suspended in clean seawater at the same temperature as the crab-rearing tanks.

\section{Artemia culture and enrichment}

Artemia nauplii (Vinh Chau strain) were hatched as described by Van Strappen (1996). Both newiy hatched or enriched Artemia nauplii were used in the experiments of this study. Artemia were enriched with Chatoceros in the same micro-algal density as for rotifer enrichment. The nauplii were also enriched with DIS " using two separate doses of $0.3 \mathrm{~g} \mathrm{~mL}^{-1}$ at a $6-\mathrm{h}$ interval). Water temperature and salinity were maintained at $30^{\circ} \mathrm{C}$ and $30 \mathrm{gL}^{-1}$, respectively, during Artemia enrichment. The density of Artemia during enrichment was $200 \mathrm{~mL}^{-1}$. Before feeding to the crab larvae, the Artemia were rinsed with disinfected seawater and suspended at a known density in seawater.

\section{Feeding}

Rotifers were fed to the crab larvae from 0 to 6 days alter hatch (DAH 0-6) [roughly corresponding to zoea 1 (Z1)-Z2 stages]. Newly hatched Artemia or Artemia meta-nauplii were offered from DAH 6 (23 stage) onwards. Rotifers and Artemia were added daily at $30-45$ and $5-10 \mathrm{~mL}^{-1}$ to the rearing tank respectively (experiments 1, 2, 3, 4, 7 and 8). For experiments 5 and 6 , live feed were fed at the required prey densities based on the planned treatments. Whenever the crab larvae were fed enriched live feed, algae- or DIS* ${ }^{*}$ enriched live feed were used on alternate days.

\section{Larval rearing experiments: objectives and experimental design}

In experiments 1, 2 and 3 , the effect of different water exchange schemes and the addition of micro-algae on larval survival and development were evaluated. In experiments 4-8. other culture aspects such as ZI stocking density, live lood density and the effect of different. prophylactic treatments were investigated. The water quality management schemes tested in experiments $1-3$ are summarized in Table 1 . An overview of the experimental design and culture conditions of all the experiments is presented in Table 2. The small-scale experiments (1-30 c) were carried out in a temperature-controlled room $\left(28-30^{\circ} \mathrm{C}\right)$. The experiments in $100 \mathrm{~L}$ tanks were performed outdoors at ambient temperature (27$31{ }^{\circ} \mathrm{C}$ ). The source and the disinfectinn procedure of the seawater for larval rearing were similar to those used for broodstock rearing. Formalin at a concentration of $20 \mu \mathrm{LL}^{-1}$ was applied every other day as a prophylactic treatment in experiments 1-6.

\section{Experiment 1}

Larval survival and growth in a ciear water system with daily partial water exchange (Clear-Batch) was compared with those in a clear water recirculating system (Clear-Recirc). In the first rearing system, $30-50 \%$ of the water was replaced daily. In the recirculating system, all rearing tanks were connected to a central binfilter. Water was recirculated at a rate of approximately $100 \%$ of the tank volume every $3-4 \mathrm{~h}$. Live food and crab larvae were retained in the rearing tanks with by a mesh screen of 70 and $300 \mu \mathrm{m}$ during the rntifer and Artemia feeding stage respectively. Larger mesh screens (250 and 500-1000 $\mu \mathrm{m}$ for roti(er and Artemia stage respectively) and higher flow 


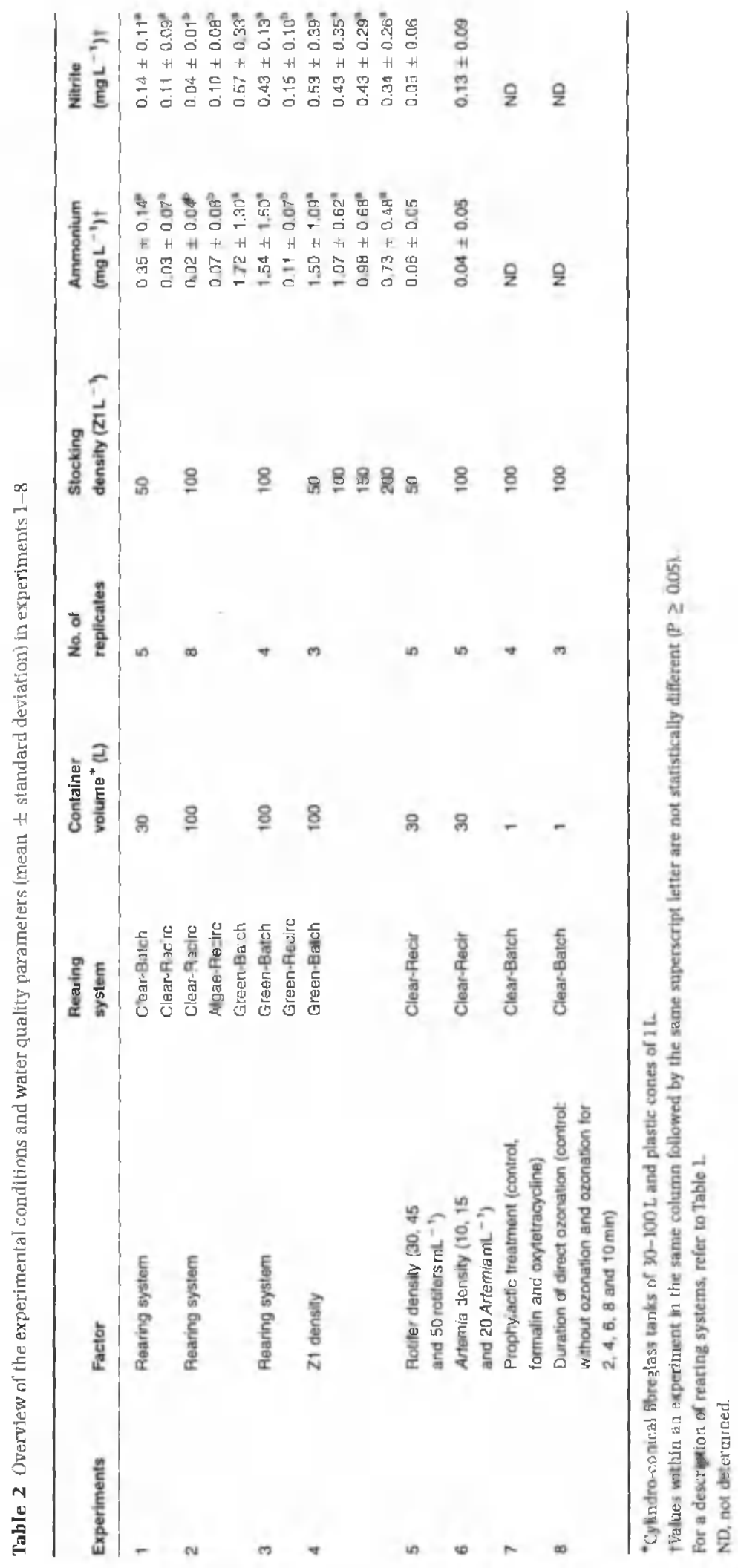


rates were used upon daily flushing out of uneaten live food and waste

\section{Experiment 2}

A Clear-Recirc system was compared with two systems where micro-algae were added. Rearing conditions for the Clear-Recirc system were similar to those described in experiment 1. In the Algae-Recirc system, micro-algae were added daily to the recirculating system at a low concentration ranging from 0.I to 0.2 million cells $\mathrm{mL}^{-1}$. The operation of the rearing tanks was similar to the Clear-Recirc treatment. In the Green-Batch treatment, a classical 'greenwater' system, micro-algae concentrations in the culture tanks were kept at a tenfold higher level of 1-2 million cells $\mathrm{rL}^{-1}$. In this system, the culture tanks were initially only filled to $50 \%$ of their capacity and gradually increased to $100 \%$ by the end of the $\mathrm{Z} 2$ stage by adding water and aigae daily. Later on, $10-30 \%$ of the rearing water was replaced daily by clean seawater and/or algae, depending on the density of micro-algae remaining in the rearing tanks. Upon water exchange, uneaten live food was also flushed out throing a mesh screen (mesh sizes as described in experiment I). The same amount of live food (30-45 rotifers $\mathrm{mI}^{-1}$ and 5-10 Artemia nauplii $\mathrm{mL}^{-1}$ ) was fed in all the treatments. In the systems using algae. Chlorella was used for $\mathrm{Z} 1-\mathrm{Z3}$ stages (which is unsuitable as a food source for Artemia); from $\mathrm{Z} 4$ onwards, Chlorella was gradually replaced with Chaetoceros.

\section{Experiment 3}

In this experiment., a Green-Batch and a Green-Recirc system were set up in order to further evaluate the application of micro-algae on the performance of crab larvae. The first rearing system was a batch system with addition of high concentrations of algae as described in experiment 2 . The second system consisted of a combination of the Green-Batch system for early crab stages (Z1-Z2) and a AIgae-Recirc system for later stages (Z3 onwards).

\section{Experiments 4-6}

In these experiments, the eflect of 71 stocking density (50, 100,150 and $200 \mathrm{~L}^{-1}$, experiment 4), rotifer leeding dersities at 30,45 and $60 \mathrm{~mL}^{-1}$ for $\mathrm{Zl}-\mathrm{Z} 2$ (experiment 5) and Artemia densities at 10, 15 and $20 \mathrm{~mL}^{-1}$ for $\mathrm{Z} 3$ onwards (experiment 6) was evaluated. These experiments were run in a Green-Batch (experiment 4) or a Clear-Recirc system (experiments 5 and 6) as described above.

\section{Experiment 7}

In experiment 7, the effect of prophylactic chemicals on the survival of the larvae was investigated. Three treatments, consisting of a control (no chemicals used), daily addition of formalin at $20 \mu \mathrm{LL}^{-1}$ and daily addition of oxytetracycline at $10 \mathrm{mg} \mathrm{L}^{-1}$, were run in $1 \mathrm{~L}$ plastic cones. All cones were placed in a water bath in order to maintain the rearing temperature at $30^{\circ} \mathrm{C}$. Water was replaced almost completely daily. Upon water exchange, the survival was determined.

\section{Experinent 8}

To avoid the use of drugs as a prophylaxis, direct ozonation of the culture tanks was tested in aerated $1 \mathrm{~L}$ plastic cones. Ozone $\left(\mathrm{O}_{3}\right)$ was injected directly via an airstone into every larval rearing cone upon changing water and feed daily. Six treatments with three replicates were arranged consisting of a control (without $\mathrm{O}_{3}$ application) and $\mathrm{O}_{3}$ injection for $2,4,6$. 8 and $10 \mathrm{~min}$ (equivalent to a residual $\mathrm{O}_{3}$ level in the water of $0.06,0.12,0.15,0.17$ and $0.19 \mathrm{mg} \mathrm{I}^{-1}$ as measured by a test kit upon finishing the injection). Other rearing conditions and daily management were similar to those described for experiment 7 .

\section{Evaluation criteria}

The survival rates in the experiments using large (30-100 L) containers (experiments 1-6) were estimated by volumetric sampling. Depending on the tank volume and the density of the surviving larvae, triplicate $300-1000 \mathrm{~mL}$ samples were taken from each tank. Megalopae (M) (DAH 15-18) and first crabs (CI) (DAH 22) were counted individually. In experiments 7 and 8 (using small cones), the average survival rate was calculated by individualiy counting all surviving larvae in each replicate.

Larval development was monitored every 3 days but daily in experinents 7 and 8 by identifying the average zoeal instar stage of a sample of larvae and assigning it a value: $\mathrm{Z1}=1, \mathrm{Z2}=2$, etc. Megalopa stage was assigned a value of 6 . To compare the larval development in each treatment, an average larval stage index (LSI) was calculated from the average LSI value of all replicate containers in the same treatment. For large containers (experiments 1-6), five or 10 larvae (in 30 and I0O L tanks respectively) were 
Table 3 Experiment: survival rates and Jarval stage index (ISI) values of Scylla parammosain larvae cultured in two different rearing systems

\begin{tabular}{|c|c|c|c|c|c|c|}
\hline \multirow[b]{2}{*}{ Trealment } & \multicolumn{6}{|c|}{ Days aller halch } \\
\hline & 3 & 6 & 9 & 12 & 15 & 18 \\
\hline \multicolumn{7}{|c|}{ Survival rate $(\%)^{*}$} \\
\hline Clear-Balch & $85 \pm 6^{3}$ & $79 \pm 9^{a}$ & $70 \pm 6^{\mathrm{B}}$ & $64 \neq 7^{a}$ & $42 \pm 6^{b}$ & $32 \pm 5^{h}$ \\
\hline Clear-Pecirc & $84 \pm 4^{A}$ & $78 \pm 8^{8}$ & $72 \pm 5^{3}$ & $70 \pm 5^{a}$ & $63 \pm 9^{2}$ & $47 \pm 6^{a}$ \\
\hline \multicolumn{7}{|l|}{ LS" } \\
\hline Clear-Batch & $1.5 \pm 0.2^{\mathrm{a}}$ & $2.7 \pm 0.1^{3}$ & $3.5 \pm 0.4^{\mathrm{a}}$ & $4.0 \pm 0.0^{a}$ & $4.6 \pm 0.2^{a}$ & ND \\
\hline Clear-Fecirc & $1.5 \pm 02^{a}$ & $2.7 \pm 0.1^{\mathrm{a}}$ & $3.6 \pm 0.3^{3}$ & $4.2 \pm 0.3^{A}$ & $4.8 \pm 0.1^{a}$ & $\mathrm{ND}$ \\
\hline
\end{tabular}

"Survival rates or LSI values in the same colimn followed by the same superscript letter are not statisticaliy different $(P \geq 0.05)$. For treatment descriptions, refer to Table 1.

ND, not determines.

sampled from each tank to calculate the average LSI. The sampled larvae were staged under a dissecting microscope. In experiment 8 , using small containers, all larvae were staged visually upon counting daily sirvival.

In this research, six larval rearing systems were applied for the experiments. Each rearing system had its own features, i.e. water quality and 'ease of operation'. Therefore, these features in combination made up a treatment as a type of rearing system. They were not considered as variables.

\section{Statistical analysis}

One-way analysis of vatiance (ANOvA) was used to compare data. Homogeneity of variance was tested with the Levene statistic ( $P$ or $\alpha$ value was set at 0.05). If no significant differences were detected between the variances, the data were submitted to a one-way anova. Tukey's honestly significant difference post hoc analysis was used to detect diflerences between means and to indicate areas of significant difference. If significant differences were detected between variances, data were transformed using the arcsine-square root (for percentage data, i.e. survival rate) or logarithmic transformations (for ISI value) (Sokal \& Rohlf 1995). All analyses were performed using the statistical program STATISTICA 6.0 .

\section{Results}

\section{Experiment 1}

Survival in the Clear-Recirc system at 74-75 stages on DAH 15 and in the megalopa stage on DAH 18 was significantly higher than those in the Clear-
Batch system (both at $P<0.01$ ) (Table 3). Although slightly higher in the recirculating system. LSI was not. significantly different between treatments. The better larval performance in the Clear-Recirc system was accompanied hy significantly lower average ammonia levels $(P<0.01)$ and slightly lower nitrite levels (see Table 2).

\section{Experiment 2}

On DAH 9. larval survival in the Clear-Recirc system was significantly lower $(P<0.05)$ than in both treatments with micro-algae supplementation (Algae-Recirc and Green-Batch systems) (Table 4). On DAH 12, survival in the Clear-Recirc treatment was lower $(P<0.05)$ than in the Algae-Recirc system, whereas the Green-Batch system had intermediate results. The LSI values on DAH 15 show a similar trend, although not significantly different.

The average levels of ammonia and nitrite in the Clenr-Recirc and Algre-Recirc systems were signifcantly lower $(P<0.01)$ than those in the Green-Batch system (see Table 2). In the Green-Batch system, peaks of ammonia and nitrtte concentrations of 3 and $\operatorname{Img~\mathrm {L}^{-1}}$, respectively. were recorded at the end of the experiment.

\section{Expcriment 3}

Table 5 presents the larval performance of the crab larvae cultured in two rearing systems. The survival rates and LSI values of both rearing systems were not significantly different. However, the survival rates on later days (from DAH 12-22) in the Green-Recirc system tended to be higher than those in the GreenBatch system. The biofilter had a positive impact on 
Table 4 Experiment 2: survival rates and larval stage index (LSI) vaiues of Scylla paramamosain larvae cultured in three different rearing systems

\begin{tabular}{|c|c|c|c|c|c|}
\hline \multirow[b]{2}{*}{ Trealment } & \multicolumn{5}{|c|}{ Days alter hatch } \\
\hline & 3 & 6 & 9 & 12 & 15 \\
\hline \multicolumn{6}{|l|}{ Survival rate $(\%)^{*}$} \\
\hline Clear-Fecirc & $74 \pm 12^{3}$ & $63 \pm 7^{a}$ & $44 \pm 6^{h}$ & $26 \pm 11^{b}$ & $8 \pm 7^{n}$ \\
\hline Algae-Recirc & $74 \pm 12^{8}$ & $63 \pm 9^{8}$ & $61 \pm 7^{A}$ & $43 \pm 7^{a}$ & $15 \pm 8^{R}$ \\
\hline Green-Batch & $74 \pm 11^{\mathrm{a}}$ & $67 \pm 9^{a}$ & $58 \pm 9^{a}$ & $35 \pm 9^{a b}$ & $13 \pm 6^{A}$ \\
\hline \multicolumn{6}{|l|}{$\mathrm{LS} \mathrm{I}^{m}$} \\
\hline Clear-Pecirc & $1.9 \pm 0.1^{\mathrm{a}}$ & $2.7 \pm 0.2^{\mathrm{A}}$ & $3.9 \pm 0.1^{\mathrm{a}}$ & $5.0 \pm 0.1^{a}$ & $5.1 \pm 0.1^{b}$ \\
\hline Algae-Recirc & $2.0 \pm 0.1^{a}$ & $2.8 \pm 0.3^{a}$ & $4.0 \pm 0.1^{\mathrm{a}}$ & $5.0+0.1^{a}$ & $5.6 \pm 0.2^{\mathrm{a}}$ \\
\hline Green-Batch & $2.0 \pm 0.1^{\text {* }}$ & $2.8 \pm 0.2^{a}$ & $4.0 \pm 0.1^{a}$ & $5.0 \pm 0.1^{\mathrm{a}}$ & $5.1 \pm 0.1^{\text {at }}$ \\
\hline
\end{tabular}

* Survival rates or LSI values in the same coiumn followed by the same superserjpt letter are not statistically different $(P \geq 0.05)$. For treatment descriptions, reler to Table $]$.

Tahle 5 Experiment 3: survival rates and Iarval stage index (LSI) values of Scylla paramanosain larvae cultured in two dif\{erent rearing systems

\begin{tabular}{|c|c|c|c|c|c|c|}
\hline \multirow[b]{2}{*}{ Treaiment } & \multicolumn{6}{|c|}{ Days after hatch } \\
\hline & 3 & 6 & 9 & 12 & 15 & 22 \\
\hline \multicolumn{7}{|c|}{ Survivai rate $(\%)^{*}$} \\
\hline Green-Batch & $94 \pm 6^{a}$ & $88 \pm 9^{a}$ & $80 \pm 2^{a}$ & $66 \pm 15^{\mathrm{a}}$ & $44 \pm 20^{\mathrm{a}}$ & $9 \pm 1^{a}$ \\
\hline Green-Fiecirc & $94 \pm 6^{a}$ & $89 \pm 8^{a}$ & $80 \pm 5^{a}$ & $68 \pm 11^{a}$ & $56 \pm 11^{a}$ & $12 \pm 3^{a}$ \\
\hline \multicolumn{7}{|l|}{ LS $\left.\right|^{*}$} \\
\hline Green-Batch & $1.4 \pm 0.3^{\text {a }}$ & $2.7 \pm 0.1^{a}$ & $3.8 \pm 0.4^{a}$ & $5.0 \pm 0.0^{a}$ & $52 \pm 0.2^{a}$ & ND \\
\hline Green-Recirc & $1.4 \pm 0.2^{\mathrm{a}}$ & $2.6 \pm 0.2^{a}$ & $3.9 \pm 0.3^{n}$ & $5.0 \pm 0.0^{2}$ & $5.3 \pm 0.1^{2}$ & ND \\
\hline
\end{tabular}

*Survival rates or LSI values in the same column followed by the same superscript letter are not statistically dillerent (P $\geq 0.05)$. For treatment descriptions, reles to Table 1.

ND, not determined

water quality in the second part of the experiment. with significantly reduced ammonia $(P<0.05)$ and nitrite $(P<0.01)$ concentrations as a consequence (seeTable 2).

\section{Experiment 4}

Table 6 shows the survival and development rate of crab larvae stocked at four different 71 densities $(50$, 100. 150 and $200 \mathrm{~L}^{-3}$ ). The survival rates were not significantly different among treatments. Only on DAH 6 was a negative correlation between LSI and Iarval density observed.

\section{Experiment 5}

Table 7 shows the survival rates and the I SI values of crab larvae fed three different rotifer densities in the 21-Z2 stages. No significant differences were found for any of the parameters. It can, however, be noticed that LSI was always the lowest in treatment 30 rotifers $m L^{-1}$ and the highest in treatment 60 rotifers $\mathrm{mL}^{-1}$.

\section{Experiment 6}

Table 8 presents the survival and development rate of crab larvae fed Artemia nauplii at three densities (In). I5 and $20 \mathrm{~mL}^{-1}$ ) from the 23 stage onwards. No sig. nificant differences were observed between the treatments. There seemed, however, to be a weak trend towards bigher survival and LSI with increasing Artemia density towards the end of the trial.

\section{Experiment 7}

Table 9 shows the survival and development rate to the megalopa stage (DAH 22) of larvae receiving different prophylactic treatments. From DAH 6 onwards, the survival rate of larvae in the treatment 
Table 6 Experiment 4: survival rates and larval stage index (LSI) values of Scylla paramamosain larvae stocked at Lour dillerent $7 \mathrm{~L}$ densities $\left(2 \perp \mathrm{L}^{-1}\right)$

\begin{tabular}{|c|c|c|c|c|c|c|}
\hline \multirow[b]{2}{*}{ Treatment } & \multicolumn{6}{|c|}{ Days after hatch } \\
\hline & 3 & 6 & 9 & 12 & 15 & 22 \\
\hline \multicolumn{7}{|c|}{ Survival rate $(\%)^{*}$} \\
\hline 50 & $79 \pm 9^{a}$ & $56 \pm 19^{a}$ & $42 \pm 16^{a}$ & $31 \pm 17^{a}$ & $28 \pm 12^{a}$ & $4 \pm 6^{a}$ \\
\hline 100 & $80 \pm 7^{a}$ & $74 \pm 6^{6}$ & $71 \pm 10^{\mathrm{a}}$ & $56 \pm 11^{\text {a }}$ & $45 \pm 8^{a}$ & $5 \pm 4^{a}$ \\
\hline 150 & $79 \pm 2^{a}$ & $57 \pm 12^{a}$ & $45 \pm 9^{A}$ & $31+12^{a}$ & $28 \pm 10^{a}$ & $5 \pm 1^{a}$ \\
\hline 200 & $85 \pm 5^{8}$ & $53 \pm i 7^{a}$ & $42 \pm 8^{\mathrm{a}}$ & $34 \pm 3^{a}$ & $30 \pm 5^{a}$ & $5 \pm 1^{a}$ \\
\hline \multicolumn{7}{|l|}{ LSI* } \\
\hline 50 & $1.7 \pm 0.2^{\mathrm{a}}$ & $3.0 \pm 0.1^{\mathrm{a}}$ & $3.9 \pm 0.1^{\mathrm{a}}$ & $5.0 \pm 0.1^{a}$ & ND & ND \\
\hline 160 & $1.8 \pm 0.1^{a}$ & $3.0 \pm 0.1^{\mathrm{ab}}$ & $4.0 \pm 0.0^{3}$ & $5.0+0.1^{3}$ & ND & ND \\
\hline 150 & $1.8 \pm c .2^{3}$ & $3.0 \pm 0.1^{a t}$ & $3.9 \pm 0.2^{\mathrm{a}}$ & $5.0 \pm 0.1^{B}$ & ND & ND \\
\hline 200 & $1.8 \pm 0.2^{a}$ & $2.7 \pm 0.1^{b}$ & $3.7 \pm 0.2^{a}$ & $4.8 \pm 0.1^{9}$ & ND & ND \\
\hline
\end{tabular}

"Survival rates or ISI values in the same column follswed by the same superscript letter are not statistically dillerent (P $\geq 0.05)$ ND, not determined.

Table 7 Experiment 5: survival rates and larval stage index (ISI) values of Scylla paramariosain larvae-fed three different rotifer densities (rotilers $\mathrm{mL}^{-1}$ ) from day 0 to day 6 after hatch

\begin{tabular}{|c|c|c|c|c|c|}
\hline \multirow[b]{2}{*}{ Treatment } & \multicolumn{5}{|c|}{ Days alter hatch } \\
\hline & 3 & 6 & 9 & 12 & 15 \\
\hline \multicolumn{6}{|c|}{ Survival rate $(\%)^{*}$} \\
\hline 30 & $89 \pm 7^{a}$ & $53 \pm 10^{a}$ & $30 \pm 8^{A}$ & $13 \pm 7^{a}$ & $10 \pm 7^{a}$ \\
\hline 45 & $87 \pm 6^{A}$ & $58 \pm 9^{a}$ & $35 \pm 7^{3}$ & $18 \pm 9^{a}$ & $14 \pm 8^{a}$ \\
\hline 60 & $87 \pm 5^{a}$ & $55 \pm 7^{2}$ & $32 \pm 6^{a}$ & $16 \pm 11^{\text {A }}$ & $11 \pm 10^{\circ}$ \\
\hline \multicolumn{6}{|l|}{ LSI $^{*}$} \\
\hline 30 & $1.8+0.2^{a}$ & $2.7 \pm 0.1^{a}$ & $3.6 \pm 0.2^{a}$ & $3.8 \pm 0.2^{\mathrm{a}}$ & $4.0 \pm 0.4^{a}$ \\
\hline 45 & $1.8 \pm 0.2^{a}$ & $2.8 \pm 0.2^{\mathrm{a}}$ & $3.8 \pm 0.1^{3}$ & $3.9 \pm 0.1^{\mathrm{a}}$ & $4.3 \pm 0.5^{\mathrm{B}}$ \\
\hline 60 & $1.8 \pm 0.2^{3}$ & $28 \pm 0.2^{x}$ & $2.8 \pm 0.2^{8}$ & $40 \pm 0.1^{a}$ & $4.4 \pm 0.5^{\mathrm{a}}$ \\
\hline
\end{tabular}

*Survival rates or LSI values in the same column fnllowed by the same superscript letter are not statistically dilferent $(P \geq 0.05)$.

using antibiotics was significantly higher than those in the remaining treatments. The survival rates of the control and formalin treatments were similar on most days. From DAH 6 onwards, the LSI values of the formalin treatment were generally higher than for the other treatments (not always significant). On DAH 15 and 18, the antibiotic treatment resulted in Iower LSI values $(\mathrm{P}<0.01)$.

\section{Experiment 8}

Table 70 presents the survival at the $\mathrm{Z} 2, \mathrm{Z3}$ and $\mathrm{Z} 4$ stages of larvae that were daily exposed to different levels of $\mathrm{O}_{3}$. On DAH 3 ( $\mathrm{Z} 2$ stage), survival in the control and the treatment with $\mathrm{O}_{3}$ injection for $2 \mathrm{~min}$ (Ozon2) was higher $(67-78 \%$ ) compared with the other treatments (24-45\%). On DAH 6 (73 stage). the survival of treatment Ozon 2 became the highest $(52 \%)$; however, this was not statistically different from the control (25\%). On DAH9, there were no significant differences in survival in all treatments.

\section{Discussion}

\section{Rearing system}

\section{Recirculation}

Water recirculation through a biofilter in the ClearRecirc system positively affected larval performance compared with manual partial water replacement in the Clear-Batch system (experiment 1). The advantages of recirculating systems in commercial fish and crustacean larval production have been proven before for other species. Research into recirculating 
Table 8 Experiment 6: survival rates and larval stage index (LSI) values of Srylla paramamosain larvae-fed three diflerent instar-1 Artemia densities (Artemia $\mathrm{mL}^{-1}$ ) from 6 days after hatch

\begin{tabular}{|c|c|c|c|}
\hline \multirow[b]{2}{*}{ Trealment } & \multicolumn{3}{|c|}{ Days after hatch } \\
\hline & g & 12 & 15 \\
\hline \multicolumn{4}{|c|}{ Survival rate $(\%)^{*}$} \\
\hline 10 & $26 \pm 10^{3}$ & $12 \pm 5^{\mathrm{s}}$ & $8 \pm 3^{n}$ \\
\hline 15 & $30 \pm 6^{a}$ & $13 \pm 7^{a}$ & $10 \pm 6^{a}$ \\
\hline 20 & $32 \pm 8^{a}$ & $19 \pm 9^{a}$ & $18 \pm 9^{*}$ \\
\hline \multicolumn{4}{|l|}{ LSI* } \\
\hline 10 & $3.1 \pm 0.2^{a}$ & $3.7 \pm 0.4^{\mathrm{a}}$ & $4.3 \pm 0.5^{a}$ \\
\hline 15 & $3.1 \pm 0.1^{a}$ & $3.7 \pm 0.2^{a}$ & $4.3 \pm 0.5^{\mathrm{a}}$ \\
\hline 20 & $3.2 \pm 0.1^{a}$ & $3.8 \pm 0.3^{\mathrm{a}}$ & $4.6 \pm 0.3^{a}$ \\
\hline
\end{tabular}

"Survival rates or LSI values in the same column foliowed by the same superscript letter are not statistically different (P $\geq 0.05)$.

Table 9 Experiment 7: survival rates and larval stage index (ISI) values of Scylla paramamosain larvae treated daily with prophylactic chernicals

\begin{tabular}{|c|c|c|c|c|c|c|c|}
\hline \multirow[b]{2}{*}{ Treatment } & \multicolumn{7}{|c|}{ Days alter hatch } \\
\hline & 3 & 6 & $\mathbf{9}$ & 12 & 15 & 18 & 22 \\
\hline \multicolumn{8}{|c|}{ Survival rates $(\%)^{*}$} \\
\hline Control & $85 \pm 3^{a}$ & $64 \pm 7^{b}$ & $48 \pm 8^{b}$ & $34 \pm 13^{b}$ & $28 \pm 11^{b}$ & $17 \pm 7^{\mathrm{b}}$ & $9 \pm 5^{\mathrm{b}}$ \\
\hline Formailn & $84 \pm 7^{a}$ & $66 \pm 8^{k}$ & $47 \pm 7^{b}$ & $34 \pm 12^{6}$ & $26 \pm 8^{b}$ & $13 \pm 10^{\mathrm{b}}$ & $11 \pm 8^{a h}$ \\
\hline Antbiotics & $91 \pm 4^{a}$ & $80 \pm 2^{a}$ & $74 \pm 4^{\mathrm{a}}$ & $66 \pm 8^{\mathrm{a}}$ & $52 \pm 6^{3}$ & $34 \pm 3^{a}$ & $21 \pm 5^{a}$ \\
\hline \multicolumn{8}{|l|}{ LSI $^{*}$} \\
\hline Cantrol & $1.9 \pm 0.1^{a}$ & $2.6 \pm 0.3^{a}$ & $3.4 \pm 0.2^{\mathrm{8b}}$ & $4.5 \pm 0.3^{\mathrm{a}}$ & $5.1 \pm 0.1^{\mathrm{a}}$ & $5.5 \pm 0.1^{b}$ & $5.8 \pm 0.2^{a}$ \\
\hline Fcrmaiin & $1.8 \pm 0.1^{a}$ & $2.8 \pm 0.1^{a}$ & $3.7 \pm 0.1^{\mathrm{B}}$ & $4.3 \pm 0.3^{\mathrm{A}}$ & $5.1 \pm 0.1^{a}$ & $5.8 \pm 0.1^{a}$ & $6.0 \pm 0.1^{a}$ \\
\hline Antibiotics & $1.9 \pm 0.0^{a}$ & $2.7 \pm 0.2^{A}$ & $3.3 \pm 0.2^{b}$ & $4.3 \pm 0.1^{a}$ & $4.9 \pm 0.1^{6}$ & $E .3 \pm 0.2^{b}$ & $5.6 \pm 0.2^{9}$ \\
\hline
\end{tabular}

* Survival rates ar ISI values in the same nolumn followed by the same superscript letter are not statistically different (P $\geq 0.05)$.

Table 10 Experiment 8: survival rates of Scylla paramamosain larvae treated daily by ozone for diflerent durations of time (min)

\begin{tabular}{|c|c|c|c|}
\hline Treatment & DAH $3(Z 2)$ & DAH G (Z3) & DAH g (Z4) \\
\hline Contral & $78 \pm 6^{a}$ & $25 \pm 9^{a b}$ & $9 \pm 6^{\mathrm{B}}$ \\
\hline Ozon2 & $67 \pm 6^{\text {ab }}$ & $52 \pm 14^{a}$ & $11 \pm 10^{a}$ \\
\hline Ozon4 & $40 \pm 17^{\mathrm{abc}}$ & $33 \pm 11^{\text {ab }}$ & $5 \pm 2^{\mathrm{a}}$ \\
\hline Ozon6 & $45 \pm 25^{a b c}$ & $27 \pm 15^{a b}$ & $5 \pm 5^{a}$ \\
\hline Otong & $31 \pm 2^{t c}$ & $19 \pm 3^{b}$ & $0 \pm 0^{a}$ \\
\hline Ozon10 & $24 \pm 15^{c}$ & $12 \pm 9^{b}$ & $0 \pm 1^{a}$ \\
\hline
\end{tabular}

Survival rates in the same column followed by the same superscript letter are not statisticaliy different $(P \geq 0.05)$.

DAH, days after hatch; Z, zoea: Contrci, without ozonation; Ozon 2, 4, 6, 8 and 10, duration of ozone injection from 2 to 10 min. which is equivalent to $0.06,0.12,0.15,0.17$ and $0.19 \mathrm{mg} \mathrm{L}^{-1}$ of the residaal czone respectivcly.

systems has also been identified as a priority for shrimp culture (Lawrence \& Lee 1997). In these systerns, water exchange is minimized through the use of biological, chemical and/or mechanical filtration to maintain good water quality continuously. As they provide less stress and confer constant good water quality to the larvae, these systems are able to main- tain a high biological carrying capacity in relatively little space (Quillere, Marie, Roux, Gosse \& Morotgaudry 1993; Twarowska, Westerman \& Losordo 1997). For crab larviculture, recirculating systems also appear to warrant further investigation in order to decrease labour requirements and seawater consumption, providing a more stable culture medinm 
and thus reducing larval stress. If the system design is kept simple, recirculating systems could also be suitahle for large-scale production.

\section{Role of supplemented nicro-algae}

The addition of micro-algae to the recirculation systems resuited in both higher survival and faster development in this study. Micro-algae have been proven to be beneficial by various modes of action. They could heip maintain the quality of live food. As in the culture of marine fish larvae, unconsumed rotifers may reside in the tanks for several days and their nutritional value may become sererely reduced (Makridis \& Olsen 1999). Furthermore, according to these authors, poorly fed rotilers were more sensitive to starvation than well-fed rotifers, as their nitrogen content decreased at a higher rate.

Micro-algae also play an important role in stabilizing water quality vil either ammonia uptake or oxygen production (Tseng, Huang \& Lian 1991). Because the Clear-Recirc system already provided optimal water quality, it is unlikely that the stabilizing effect on water quality is responsible for the improved performance in the algae-supplemented system. In batch culture systems, this effect would probably be much more pronounced. A direct comparison between a green and clear water batch system was. however, not made in this study.

In a study on the effect of Chlorella on the population of luminous bacteria Vibrio harveyi, no luminous bacteria were recovered on days 2 and 3 in flasks with Chlorella, while those without the micro-algae still harhoured luminous bacteria at day 3 (Tendencia \& dela Pena 2003). Also, the diatom Chaetoceros has been shown to produce natural antibiotics and high concentrations of this marine diatorn will eliminate Vibrio vulniffrus and other pathogenic bacteria, which contribute to the propagation of viruses in the shrimp production environment (Wang 2003).

In conclusion, micro-algae in mud crab larval rearing may play a role in improving and maintaining live food quality and controlling bacteria Ievels.

\section{Choise of system}

In experiment 3, the Green-Recirc system (which is a combination of a Green-Batch system during the rotifer feeding stage and a Algae-Recirc system thereafter) seemed to be better than the Green-Batch system. The Green-Batch system seems to be more appropriate for early stages of crab larvae (Z1-Z2) as it is less stressful for the early zoeae and easier to gra- dually fill up the tanks with fresh seawater, algae and rotifers than flushing out old rotifers in the recirculation system. In the recirculating system, the young larvae may be prone to physical damage and may spend considerable energy trying to swim up against the current. Early crab larvae are delicate due to their small size and the three long spines on the carapace that are easily damaged when they are entrapped on the mest screen during flushing out of uneaten feed in the recirculation system (Davis 2003). The nutritional effect of micro-algae is probably also more pronounced during the rotifer feeding stage than during the Artemia feeding stage. Furthermore, it is not necessary to recirculate water during these first days. as the concentrations of ammonia and nitrite are still low. Using the Aigae-Recirc system in later stages is more favourable for reducing the increasing ammonia and nitrite concentrations as more waste materal is produced by the crab larvae. Moreover, as the larvae develop into more efficient predators, feed is consumed faster, and maintenance of optimal feed guality is less of an issue. Many studies successfully applied a similar combined rearing technique due to its benefit for the larvae and convenience for management. particularly for large rearing containers. Under green-water culture conditions, water is not exchanged for the first 3 days. Therealter, water exchange is slowly increased from $10-20 \% \mathrm{day}^{-1}$ for $\mathrm{Z} 2-\mathrm{Z3}$ to between $40 \%$ and $50 \%$ day $^{-1}$ at the end of the rearing cycle (Z4-M) (Mann. Asakawa \& Pizzuto 1999: Quinitio, Parado-Estepa, Millamena, Rodriguez \& Borlongan 2001). In Japan, a mesocosm system is used for culturing larvae in larger tanks $\left(>10 \mathrm{~m}^{3}\right)$. The tanks are partialiy filled with green water at ZI (20-25\% volume), tanks are then filled up with clean seawater during the course of the Z2-Z3 stages and during the $\mathrm{Z} 4$ and $\mathrm{M}$ stages water is exchanged on a flow-to-waste basis (Hamasaki, Suprayudi \& Takeuchi 2002).

\section{Other rearing techniques}

\section{Zl stocking density}

No significant effect of Iarval density was observed from 50 to $200 \mathrm{ZI} \mathrm{L} \mathrm{L}^{-1}$. This would suggest that the larvae can be grown at $200 \mathrm{Zl} \mathrm{L}^{-1}$. Variation in the final survival between replicate tanks also seemed to decrease at higher densities. For S. paramamosain, Djunaidah, Mardjono, Wille, Kontara and Sorgeloos (2001) found a tendency of increased survival to Z.5 as a function of the Z1 stocking densify (i.e. surviva? 
rates of $27 \%, 39 \%$ and $63 \%$ being obtained at densities of 50.75 and $100 \mathrm{Z1} \mathrm{L}^{-1}$ respectively). Baylon and Failaman (1999) also reported higher survival and metamorphosis of Scylla serrata at $50 \mathrm{Z}^{\mathrm{L}} \mathrm{L}^{-1} \mathrm{com}-$ pared with lower densities of 10 and $257 \mathrm{IL}^{-1}$. Increased survival at higher larval densities somehow seems contradictory. However, indirectly, food ration might be responsible. Excess food in treatments with low larval densities may pollute the water and may thus cause mortality. In our study, we noted higher concentrations of ammonia and nitrite in the treatment having $50 \mathrm{Zl} \mathrm{L}^{-1}$ (see Table 2). For the highest stocking densities tested in our study $\left(200 \mathrm{Zl} \mathrm{L}^{-1}\right)$, the larval development rate seemed slightly impaired. This high stocking density may have caused competition for feed, resulting in slower development. Therefore, 21 stocking densities in the range of

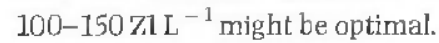

\section{Rotifer density for feeding early larval stages (Z1-Z2 stages)}

Although there was a trend towards increased survival and growth with increasing rotifer density, no significant diflerences in larval survival or growth were found between the different rotifer densities tested. Although not significant, the highest survival was generally observed at 45 rotifers $\mathrm{mL}^{-1}$; while a density of 60 rotifers $\mathrm{mL}^{-1}$ resulted in the fastest larval development. The differences were, however, not very marked, and moreover such high feeding rates might be economically unrealistic. We can therefore conclude that feeding 30 rotifers $\mathrm{mL}^{-1}$ is enough for optimal larval performance. In practice, however, the intermediate density of 45 rotifers mi ${ }^{-1}$ was frequently used for feeding early larval stages. Other studies indicated that high rotifer densities $\left(30-80 \mathrm{~mL}^{-1}\right)$ are required for optimal growth and survival of $S$. paramamosain (Djunaidah, Mardjono, Lavens \& Wille 1998; Zeng \& Li 1999) and S. serrata (Suprayudi, Takeuchi. Hamasaki \& Hirokawa 2002). For $S$. paramamosain larvae, feeding 30 and 60 rotifers $\mathrm{mL}^{-1}$ resulted in a significantly higher survival compared with feeding only 15 rotifers $\mathrm{mL}^{-1}$ (Djunaidah et al. 2001). These authors found that the individual dry weight of Z5fed 15 rotifers $\mathrm{mL}^{-1}$ was significantly lower than those of $\mathrm{Z} 5$ fed with higher rotifer densities. Practically, feeding 30 rotifers $\mathrm{ml}^{-1}$ at $\mathrm{Zl}$ and increasing gradualiy to $45 \mathrm{~mL}^{-1}$ at $\mathrm{Z} 2$ proved to be sufficient for a stocking density o[ $1007 \mathrm{I} \mathrm{L}^{-1}$ in our trinls in larger rearing tanks (500-1000 L). Increasing the ra- tion by larval stages in this way compensates for the increased ingestion of crab larvae as they grow (Baylon. Bravo \& Manigo 2004). For early larvae, however, food amount cannot be reduced to their maximum ingestion potential as they are quite ineffcient predators and therefore might require a minimal density to maximize encounter.

Similar to our study, most studies investigating the effect of rotifer density added the live food in one single ration. Under these circumstances, theoretic densities are only attained upon feeding and gradually decrease as larvae consume the prey, Optimal live food quantities cannot, however, be separated from feeding frequency. Because zoea larvae can consume their optimal ration within $1 \mathbf{h}$, Genodepa, Southgate and 7eng (2004) suggested that they can be fed once a day. Because of the severe reduction in the nutritional value of rotilers with longer retention times in rearing containers (Makridis \& Olsen 1999) and the fact there is a minimum prey density needed for the passive leeding behaviour of zoea larvae (Heasman \& Fielder 1983; Zeng \& Li 1999), the interaction between the optimal ration and feeding frequency should be further investigated.

\section{Artemia for feeding later larval stages (from $\mathrm{Z} 3$ onwards)}

We found no difference between feeding $\mathrm{Z} 3$ a daily feed ration of 10.15 or 20 Artemia nauplif $\mathrm{mL}^{-1}$. Especially in later larval stages (Z4-Z5), there was, however, a tendency towards higher survival with increasing ration. In this respect, it might be beneficial to increase the Artemia density by crab stage from 10 to $15 \mathrm{~mL}^{-1}$. High live feed densities would increase the chance for eariy larvae to encounter and capture feed organisms (Zeng \& Li 1999) and therefore would improve the larval performance (Brick 1974; Heasman \& Fielder 1983; Quinitio et al. 2001). On the other hand, older larval have a higher ingestion capacity. Optimal rations should therefore be determined for each larval stage separately. In this respect, studies on individual larvae are very uselul to determine prey consumption. According to our previous experiments (Nghia 2004), each 23, Z4, Z5 and megalopa larva was capable of consuming on average 15, 25, 37 and 114 newly hatched Artemia day ${ }^{-1}$ respectively. Therefore, at a stocking of 100 larvae $\mathrm{L}^{-1}$, the daily Artemia feeding densities theoretically should be at least 1.5, 2.5, 3.7 and $11.4 \mathrm{~mL}^{-1}$ for $\mathrm{Z3}, \mathrm{Z4}, 25$ and megaìpa stages respectively. For ZI, Z2 and Z3 stages of S. serrata, the 
number of Artemia nawplit ingested by the larvae at a Iower food density of $2.5 \mathrm{~mL}^{-1}$ was comparable to that at $5 \mathrm{~mL}^{-1}$, and for $24-\mathrm{Z} 5$, at $5 \mathrm{~mL}^{-1}$, it was comparable to $10 \mathrm{~mL}^{-1}$ (Baylon et al. 2004). In that study, Artemia was, however, co-fed with rotifers at a density of $15-20 \mathrm{~mL}^{-1}$. If Artenia was the only food, the optimal Artemia ration would therefore probabiy be higher than $2.5-5 \mathrm{~mL}^{-1}$. In another study on $S$. serrata, a daily optimum food concentration of $10 \mathrm{Ar}-$ temia nauplìi $\mathrm{mL}^{-1}$ was established for zcea survival (Brick 1974). In the mass seed production of S. serrata newly hatched Artenia are given starting late $\mathrm{Z} 2$ at 0.5-3 $\mathrm{mL}^{-1}$ and 5-7-day-old Artemia are routine fed from late $\mathrm{Z} 5$ to early megalopa (Quinitio \& ParadoEstapa 2003). Older Artemia provided a larger-sized prey for zoeae to megrlopae and hence, the density was reduced.

For megalopae of $S$. paramamosain, we lound a threefoid higher number of ingested newly hatched Artemia nauplii compared with Z5 (114 and 37 Artemia respectively) for a similar prey density (Nghia 2004). This means that megalopae are voracious predators, capable of chasing their prey actively and consume large amounts of feed in a short time. From this, it could be beneficial if megalopae are fed frequently smaller rations in order to optimize feed quality and reduce cannibalísm. Gencdepa et al (2004) similarly indicated that in contrast to earlier larval stages, which can be fed once per day, S. serrata megalopae may need to be fed more often to maximize ingestion. These authors found no significant differences in the ingestion rate of megalopae fed microbound diets at rations ranging from $12.5 \%$ to $100 \%$ of the standard ration (equivalent to 5 Artemia nauplii $\mathrm{mL}^{-2}$ in I h). Baylon et al (2004) also found a high increase in Artemia ingestion in the first few days of the planktonic phase of the megalopa stage. Later on, megalopae become more benthic as they prepare for the second metamorphosis to first crab. Swimming Artemia are no longer accessible, and minced shrimp or mussel meat are a more suitable feed.

In conclusion, a ration of 10 Artemia naupli1 $\mathrm{mL}^{-3}$ appears to be sufficient for the optimal performance of $\mathrm{Z} 3$ larvae. An increase in prey density in the Z4-Z5 stage may, however, be beneficial. These lood amounts appear to be higher than what most other studies recommend (2.5-10 Artemia nauplii $\mathrm{mL}^{-1}$; Rrick 1974; Baylon et al. 2004). Perhaps the recirculating system used in this study resulted in a greater loss of prey organisms (e.g. more Artemia were entrapped on the overflow screen) than in the small batch culture systems used in other experiments. The small nauplii size of the Artemia strain (Vinh Chau strain) used in our study could be another reason that led to increased ingestion. In practice, (larger sized) highly unsaturated fatty acid-enriched Artemia were normally used in order to reduce the prey amount to $5-10 \mathrm{ml}{ }^{-1}$. Megalopa probably should be fed more frequently and, towards the end of that developmental st.age., a non-moving lood may be better.

\section{Prophylactic chemicals}

Laboratory cultures of crab larvae often suffer severe mortality from disease, particularly from epibiotic hacteria and larval mycosis (Armstrong, Buchanan \& Caldwell 1976; Hamasaki \& Hatai 1993a, b). A study on S. serrata indicated a significantly higher survival up to DAH 7 (over $90 \%$ ) when using oxy tetracycline. whereas almost complete mortality occurred in the control treatment (Mann 2001). The author considered that potentially up to $80 \%$ of the larval mortality could be attributed to bacteriological causes. The results of our study also indicated that bacteria are, more than any other factor tested, a main cause of larval mortality. Antibiotics more than doubled survival up to the crab stage.

However, antibiotics have not always been used in a responsible manner in aquaculture. A major consequence of using antibiotics has been the proliferation of resistant bacteria and the transmission of resistance to other bacterial species (Benson 1998). The develnpment of antibiotic resistance by pathogenic bacteria is considered to be one of the most serious risks to human health at the global level (EAO 2002). Formalin is more acceptable than antibiotics as it shows no accumulation in animal tissues (Jung, Kim, Jeon \& Iee 2001). Recently, however, Japan has strictly banned the use of formalin in aquaculture as it may cause cancer in humans, reduces oxygen levels in the water and causes algae to die off (VASEP 2003). Moreover, in our experiments, formalin did not significantly improve larval survival compared with the negative control. Pathogenic bacteria are considered to be one of the most serious causes for the high mortality of early crab larvae. It can be safely assumed that all inputs (seawater, broodstock, live feed and daily management in hatcheries) into the culture tank are potential sources of infection (Blackshaw 2001). Strict hygiene at all steps is always advised for hatchery activities. However, this advice is not always followed. especially in backyard hatcheries. Therefore, orher techniques should be 
investigated as alternatives for the use of chemicals. Ozonation and probiotics could be interesting in this respect (Davis 2003; Nghia 2004). Ozone is a powerful oxidant and is becoming more and more popular in various aquaculture systems for disinfection and improving water quality by oxidation of inorganic and/or organic compounds (Tango \& Gagnon 2003). In our study, direct application did not significantly improve survival compared with a negative control. However, there was a tendency of a residual $\mathrm{O}_{3}$ concentration of $0.06 \mathrm{mg} \mathrm{T}^{-1}$ to improve larval performance. Variahility within this treatment was, however, very high. which could be indicative of the fact that dosing was not careful enough. Ionger $\mathrm{O}_{3}$ exposure times (4-10-min exposure, equivalent to $0.12-0.19 \mathrm{mg} \mathrm{L}^{-1}$ residual $\mathrm{O}_{3}$ ) all decreased overal] survival. These high $O_{3}$ concentrations probably caused physical damage to the crab larvae. In Penaeus monodon juveniles, $0.34-0.5 \mathrm{mg} \mathrm{L}^{-1}$ residual $\mathrm{O}_{3}$ caused loss of balance, immobility and destruction of the gill lamellar epithelium (Meunpol, Lopinyosiri \& Menasveta 2003). Ozone treatment should therefore be investigated further, with determination of proper doses for each larval stage. Ultimately, the microbial flora will need to be controlled and there is evidence that this can be achieved using recirculating systems in which $\mathrm{O}_{3}$ treatment is combined with the inoculation of the biological fitter with selected nitrifying and probiotic bacteria (Gatesoupe 1991; Rombaut, Suantika, Bonn, Maertens, Dhert, Top, Sorgeloos \& Verstraete 2001).

\section{Conclusions and suggestions}

The combination of a green-water batch system for early stages and a recirculating system with microalgae supplementation for later stages, a stocking density of 100-150 $\mathrm{Zl} \mathrm{L}^{-1}$. feeding density of 3045 rotifers $\mathrm{mL}^{-1}$ for early stages and $10-15$ Artemia nauplii $m \mathrm{~L}^{-1}$ for later stages are recommended for larval rearing of $S$. paramamosain.

The optimal raticn for crab larvae should, however, be adjusted depending on various factors, e.g. species. larval stages, larval status, prey size, rearing system and rearing techniques. A feeding regime with frequent addition of small quantities of feed is worth investigating

Antibintics improved larval survival, proving again that bacterial interference is one of the major causes of mortality. Formalin could not significantly improve survival compared with the control. Both products, moreover, are not encouraged for commercial mud crab lervicultuxe as they are unsafe. Direct ozonation as an alternative to prophylactic chemicals is worth investigating.

\section{Acknowledgments}

This study was supported by the European Commission (INCO-DC) through the project grant No ICA4CT-2001-10022 'Culture and management of Scylla species', the Flemish Inter-Iniversity Council (VLIRIUC) and the International Foundation for Science (IES) through the reserrch grant agreement No A/ 2505-1 'Improvement of larviculture of the mud crab (Scylla paramamosain) in the Mekong Deita, Vietnam?

\section{References}

Angell C.A. (1992) The mud crab In: Report of the Seminar on the Mud Crab Culture and Trade (BOBP/RFP/51, Eay of Bengal Programme, Madrns, India), Surat Thani, Thailand. 5-8 November 199 I (ed. by C.A. Angeli). 246pp.

Armstrong D.A, Buchanan D.V. \& Caldwell R.S. (1976) A mycosis caused by Lagenidium spp. in laboratory reared larvae of the Dungeness crab, Cancer magister, and possible chemical treatments. Journnl of Invertebrate Pathology 28. 329-336

Baylon J.C. \& Failaman A.N. (1999) Larval rearing of mud crab Scylla sertata in the Philippines. In: Mud Crab Aquaculture and Biology, Proceedings of an Infernational Scientife Forum, Darwin, Anstralia, 21-24 April 1997, ACIAR Proceedings No. 78 (ed. ty C.P. Keenan \& A. Blackshaw), pp. 14I-146. Australian Centre for International Agricultural Research, Canberra, Australia.

Baylon J.C., Bravo M.E.A. \& Manigo C. (2004) Ingestion of Brachionus plicatilis and Artemia salina nauplij by mud crab Scylla serrata larvae. Aquaculture Research 35, 62-70.

Benson S.M. (7998) Reservoirs of resistance. Today's Life Science 10

Blackshaw A.W. (2001) Larval cuiture of Scyllia serrata: maintenance of hygiene and concepts of experimental design. Asian Fisheries Science 14, 239-242.

Brick R.W. (1974) Effect of water quality, antibiotics, phytoplenkton and food on survival and development of larvae of Scylla serrata (Crustacea: Portunidae). Aquaculture 3. 231-244.

Davis J.A. (2003) Development of hatchery techniques for the mud crab Scyllin serrata (Forsskal) in Simth Africa. PhD thesis, Facuity of Agricultural and Applied Biological Sciences, Ghent University, Belgium, 163pp.

Dhert P. (1996) Rotifers. In: Manual on the Production and Use of Live Food for Aqualuiltare. FAO Technical Paper No. 361 (ed. hy P. Lavens \& P. Sorgeloos). pp. 61-100. Eood and 
Agriculture Organization of the United Nation, Rome, Italy.

Djunaidah I.S., Mardjono M., Lavens P. \& Wiile M. (1998) Elfects of light and feeding regimen on culture performance of mud crab (Scylla spp) larvae. In: Culture of Portunid Crabs, Extended Abstracts of the Internutional Forum, Boracay, Philippines, I-4 December 1998 (ed. by C. Keenan. O Millamena \& E.T. Quinjtin), Fp. 27-28. SEAFDEC, Tigbauan, Philippines.

Djunaidah L.S. Mardjono M. Wille M. Kontara E.K. \& Sorgeioos F. (2001) Investigations on standard rearing technjques for mass production of mud crab Scyllia spp. seed. A research review. In: Mud Crab Rearing, Ecology and Fisheries, Book of Abstrncts of 2001 Workshop, Can Tho University, Vietnam. 8-In January 2001 (ed, by L. Le Vay, R. Sorgeloos, M. Wilie, TT. Nghiz \& V.N. Ut), p. 11. Institute for Marine Aquaculture (IMA) - Can Tho University, Can Tho City, Vietnam.

FAO (1999) Aquaculture production statistirs 1988-1997. FAO 6isheries Circular No. 815, Revision 1I, Rome, Italy, 20.3pp.

FAO (2CO2) The state of world fisheries and aquaculture. See http://www. Iao.org/docrep/

Gatesoupe F.J. (1991) The ellect of three strains of lactic hacteria on the production rate of rotifers, Brachionus plicatilis, and their dietary value for larval turbot Scopthalmus maximus. Aquasulture 96. 335-342.

Genodepa J., Southgate R.C. \& 7.eng C. (2004) Diet particle size preference and optimal raticn for mud crah, Scylla serrata, Iarvae fed microbound diets. Aquaculture 230. 493-505.

Hamasaki K. \& Hatai K. (1993a) Experimental infection in the eggs and larvae of the swimming crab Portunus trit urbiculatus and the mud crab Scylla serrata with seven fungal strains belonging to Lagenidiales. Bulletin of the Japanese Soriety of Scientific Fishreries 59, 1059-1066.

Hamasaki K. \& Hatai K. (1993b) Prevention of fungal infection in the eggs and larvae of the swimming crab Portunus trituberculatus and the mud crab Scyllo serrata by tath treatment with formalin. Bulletin of the Japanese Society of Scientific Fisheries 59, 1067-1072.

Hamasaki K., Suprayudi M.A. \& Takeuchi T. (2002) Mass mortality during metamorphosis to megalops in the seed production of mud crab Srylla serrata (Crustacea, Decapoda, Portunidae). Fisheries Science 68, 1226-1231.

Heasman M.P. \& Fielder D.R. (1983) Labcratory spawning and mass larval rearing of the mangrove crab Scylla serrata (Forsskảl), from first zoea to first crab stage. Aquaculture 34, 30.3-316

Howell B.R., Day O.J., Ellis T. \& Baynes S.M. (1998) Early stages n f farmed fish. In: The Biology of Farmed Fish (ed. by K.D. Black \& A.D. Pickering), Sheffield Academic Press, Shefilield, UK, 415pp.

Jung S.H., Kim ].W., Jeon L.G. \& LeeY.H. (200t) Formaldehyde residues in formalin-treated olive flounder (Paralichthys olivaceus), black rocksish (Sebas1 es schlegeii), and seawatex. Aqnaculture 194, 253-262.
Keenan C.. (1999a) Aquaculture of the mud crab, genus Scylla-past, present and future. In: MudCrab Aquaculture and Biology, Proceedings of an International Scientific Forumı, Darwin, Anstralia, 21-24 April 1997, AClAR Proceedings No. 78 (ed. by C.P. Keenan \& A. Blackshaw), pp. 9-13. Australian Centre for International Agricultural Research, Canberra, Austrailia.

Keenan C.P. (1999b) The fourth species of Scylla. In: Mud Crab Aquaculture and Biology. Proceedings of ar International Scientific Forum, Darwin. Anstralia, 21-24 April 1997, ACIAR Proceedings No. 78 (ed. by C.P. Keenan \& A. Blackshaw), pp. 48-58. Australian Centre for International Agricuitural Research, Canberra. Australia.

Keenan C.P., Davie P.J.F. \& Mann D.L. (1998) A revision of the genus Scyliła de Haan, 1833 (Cruslacea: Decapoda: Brachchyura: Portunidae). The Raffles Bulletin of Zoalogy $\mathbf{4 6}$, $217-245$.

Lawrence A.L. \& Lee P.G. (1997) Research in the Americas. In: Cristacean Nutrition (ed. by L. D'Alramo, D Conklin \& D. Akiyama), pp. 566-587. World Aquaculture Society, Baton Rouge, LA, USA.

Liong R.C. (1992) The fattening and culture of mud crab (Srylla serrafa) in Malaysia. In: Report of the Seminar on the Mud Crab Culture andTrade (BOBP/REP/51, Bay of Bengal Programme, Madras, India), Surat Thani, Thailand, 5-8 November 1991 (ed. by C.A. Angell), pp. 185-190.

Makridis P. \& Olsen Y. (1999) Protein depletion of the rotifer Brachionus plicatilis during starvation. Aquaculture 174, 343-353.

Marn D. (2001) The influence of microbiology on the success of mud crab larval culture. In: Mud Crab Rearing, Ecology and Fisheries, Bonk of Abstracts of 2001 Workshop. Can Tho University, Vietnam, 8-10 January 2001 (ed. by L. Le Vay, P. Sorgelnos, M. Wilie, T,T. Nghia \& V.N. Ut), Ep. 18-21. Institute for Marine Aquaculture (IMA) Can Tho University, Can Tho City, Vietnam.

Mann D. Asakawa T. \& Pizzuto M. (1999) Development of a hatchery system for larvae of the mud crab Scylla serrata at the Bribie Island Aquaculture Research Center. In: Mud Crah Aquaculture and Biology, Proceedings of an hiternational Scientffic Forum, Dorwin, Aristralia, 21-24 April 1997. AClaR Procedings No. 78 (ed. by C.P. Keenan \& A. Blackshaw). p. 153-158. Australian Centre for International Agricultural Research, Canberra, Australia.

Mann D.L. Asakawa T., Pizzuto M. Keenan C.P. \& Brock I.J. (200I) Investigation of an Artemia-based diet for larvae of the mudi crab Scylla serrata. Asian Fisheries Science 14, 175-184.

Meunpol O., Lopinyosiri K. \& Menasveta P. (2003) The effects of oznne and probiotics on the survival of black tiger shrimp (Penaets monodon). squaculture 220, 437-448.

Nghia T.T. (2004) Optimization of mud crah (Scylla paranamnsain) larviculture in Viemam. $\mathrm{PhD}$ thesis, Faculty of Agricultural and Applied Biological Sciences, Ghent University, Belgium, $192 \mathrm{pp}$. 
Quillere I., Marie D., Roux L., Gosse E \& Morot-Gaudry J.E. (1993) An artificial productive ecosystem based on a fish: bacteria: plant association. 1. Design and managernent. Agriculture Ecosystems and Environnent 47, 13-30.

Quinitio E.T. Parado-Estepa F. Millamena O.M., Redriguez E. \& Borlongan E. (2001) Seed production of mud crab Scylla serrata juveniles. Asian Fisheries Science 14, 16I-174.

Quinitio E.T. \& Parado-Estapa F.D. (2003) Binlogy and hatchery of mud crobs. Scylla spp. SEAFDFC. Tigbauan, Philippines, 42pp.

Rattanachote A. \& Dangwatanakul R. (1992) Mud crab (Scylla serrata Forssikål) fattening in Surat Thani province. In: Report of the Seminar on the Mud Crab Culture and Trade. (BOBP/REP/51. Bay of Bengal Programme, Madras, India) Surat Thani, Thailand, 5-8 November 1991 (ed. by C.A. Angell), pp. 171-177.

Rombaut. G., Suantika G., Boon N., Maertens S., Dhert P., Top E. Sorgeinos P. \& Verstraete W. (2001) Monitoring of the evolving diversity of the microhial community present in rotifer culture. Aquaculture 198. 237-252.

Shelbourne j.E. (1964) The artificial propagalion of marine fish. Advances in Marine Biology 2, 1-83.

Shelley C. \& Fieid D. (1999) The culture of Portunid crabs. Infofish International 4, 46-49.

Sokal R.R. \& Rohlf F.J. (1995) Biometry: The Principles and Practice of Statistics in Biological Research, 3rd edn. W.H. Freeman and Company, New York, NY, IJSA, 887pp.

Sorgeloos P. \& Lavens P. \{1996) Manual on the Production and Use of Live Food for Aqnaculture. Eisheries Technical Paper Vol. 361. Food and Agriculture Organization of the United Nation, Rome, Italy pp. 9-100.

Sorgeloos P. \& Léger P. (1992) Inproved larvicuiture outputs of marine fish, shrimp and prawn. Journal of the World Aquaculture Society 23, 251-264

Suprayudi M., Takeuchi T., Hamasaki K. \& Hirokawa J. (2002) Effect of Artemia feeding schedule and density on the survival and development of larvai mud crab Snyllo serrata. Fisheries Science 68, 1295-1308.

Tango M.S. \& Gagnon G.A. (2003) Impact of ozanation on water quality in marine recirculation systems. Aquacultural Engineering 29, 125-137.
Tendencia E.A. \& dela Peòa M. (2003) Investigation of some components of the greenwater system which makes it eflective in the initial control of luminous bacteria. Aquaculture 218, 115-119.

Tseng K.F. Huang J.S. \& Ljao LC. (1991) Species control of microalgae in an aquacuiture pond. Water Research 25. 1431-1437.

Twarowska J.G., Westerman P.W. \& Losordo T.M. (1997) Water trealment and waste characterization evaluation of intensive recirculating fish production system. Aquaculture Engineering 16, 133-147.

Van Stappen G. (1996) Artemin. In: Manual on the Production and Use of Live Food for Aquanculiture. FAO Technicnl Paper No. 367 (ed. hy P. Lavens \& P. Sorgeloos), pp. 101-170. Food and Agriculture Organization of the United Nation, Rome, Italy.

VASEP. (2003) Japan banned on using formalin in aquaculture (in Vietnamese). Magazine of Vietnam Association of Seafood Fxporters and Producers, May 2003.

Wang J.K. (2003) Conceptual design of a microalgae-based recirculating oyster and shrimp system. Aquncultural Engineering 28, 37-46.

Xuan T.T. (2001) The status and the prospect of muderab culture in Ca Mau province, Vietnam. In: Mrd Crab Rearing. Ecology and Fisheries, Book of Alstracts of 2007 Workshop, Can Tho University, Vietnam, 8-10 January 2001 (ed. by L. Le Vay, P. Sorgeloos, M. Wille, T.T. Nghia \& V.N Ut), p. 28. Institute for Marine Aquaculture (IMA) - Can Tho University, Can Tho City, Vietnam.

Zeng C. \& I.i S. (1999) Effects of density and different combinations of diets on survical, development. dry weight and chemical composition of larvae of the mud crab Scylla paranamosain. In: Mud Crob Aquaculture and Biology. Proceedings of an International Scientific Forum, Dnl'win, Aistralia, 21-24 April 1997, ACIAR Proceedings No. 78 (ed. by C.P. Keenan \& A. Blackshaw), pp. 159-166. Australian Centre Cor International Agricultural Research. Canberra, Australia. 